\title{
Eksekusi putusan hakim dalam sengketa perdata di Pengadilan Negeri Sleman
}

\author{
Sri Hartini, Setiati Widihastuti, dan Iffah Nurhayati \\ Universitas Negeri Yogyakarta \\ sri_hartini@uny.ac.id
}

\begin{abstract}
This article is based on research intended at describing the execution of verdict of private case in court of Sleman Regency and its obstacles. It was a descriptive qualitative research. It was found that the execution of verdict of private case in court of Sleman Regency begins by accusation or submission of execution by appellant and ends execution by confiscation. Its obstacle was: (1) its high cost as burdance of appellant; (2) the lack of qualified personel; and (3) the rivalry or rejection of accused. The efforts to overcome these obstacles were: (1) the chief of regency court encourages both sides to compromise between initiator of accusation and his/her rival (accused) peacefully; (2) send a personel substitute of seizure in calling conflicting side and proposing additional personel but not yet successful; and (3) the personel of seizure inform or sends the unsolved problem through electronic devices to Sleman Regency in order to suspend its execution.
\end{abstract}

\section{Keywords: execution, verdict, private law}

\section{Pendahuluan}

Manusia sebagai makhluk zoon politicon dalam kehidupan bermasyarakat akan selalu berhubungan satu sama lain. Hubungan tersebut dapat berupa hubungan yang menyenangkan maupun hubungan yang menumbuhkan pertentangan atau konflik atau sengketa. Pertentangan atau konflik tersebut tentu saja akan mengganggu tatanan masyarakat. Oleh karena itu keseimbangan tatanan masyarakat yang terganggu tersebut harus dipulihkan ke keadaan semula.

Di dalam negara yang berdasar atas hukum cara menyelesaikan konflik atau pertentangan/sengketa tidak boleh dengan cara menghakimi sendiri melainkan dengan cara yang diatur sesuai dengan peraturan perundang-undangan yang berlaku. Salah satu cara yang dapat ditempuh untuk menyelesaikan konflik atau pertentangan atau sengketa tersebut yakni melalui pengadilan.

Penyelesaian sengketa di pengadilan pada dasarnya dilakukan secara sederhana, cepat dan biaya ringan sebagaimana ditentukan dalam Undang-Undang Nomor 48 tahun 2009 tentang Kekuasaan Kehakiman Pasal 2 ayat (4), Pasal 4 ayat (2), HIR Pasal 121 ayat (4), 182, 183 dan Rbg Pasal 145 ayat (4), Pasal 192 dan Pasal194. Namun tidak dapat dimungkiri bahwa dalam berperkara di pengadilan khususnya dalam beracara perdata memerlukan tenaga, waktu dan biaya yang tidak sedikit. Di samping itu beracara perdata di pengadilan dapat memakan waktu berbulan-bulan bahkan bertahun-tahun. Hal ini terjadi apabila semua upaya hukum terhadap putusan ditempuh baik dari tingkat banding, kasasi maupun peninjauan kembali.

Suatu perkara/sengketa diajukan oleh pihak yang merasa dirugikan kepada pengadilan untuk mendapatkan penyelesaian atau pemecahan. Pemeriksaan perkara memang diakhiri dengan putusan, akan tetapi dengan dijatuhkannya putusan saja belumlah selesai persoalannya. Putusan itu harus dapat dilaksanakan atau dijalankan (eksekusi). Suatu putusan pengadilan tidak ada artinya bagi pihak yang dimenangkan apabila tidak 
dilaksanakan. Oleh karena itu putusan hakim mempunyai kekuatan eksekutorial, yaitu kekuatan untuk dilaksanakan apa yang ditetapkan dalam putusan itu secara paksa oleh alat-alat negara. Adapun yang memberi kekuatan eksekutorial, pada putusan hakim ialah kepala putusan yang berbunyi "Demi Keadilan Berdasarkan Ketuhanan Yang Maha Esa" (Mertokusumo, 1999, p. 183). Hal ini sesuai dengan UU No. 48 tahun 2009 pada Pasal 2 ayat (1) bahwa peradilan dilakukan "Demi Keadilan Berdasarkan Ketuhanan Yang Maha Esa".

Hanya putusan hakim yang bersifat condemnatoir (putusan yang amar atau diktumnya mengandung unsur "penghukuman") saja yang dapat dilaksanakan, sedang putusan hakim yang bersifat konstitutif dan declaratoir tidak memerlukan sarana-sarana pemaksa untuk melaksanakannya "non-executable" (Harahap, 1988, p. 11). Hal ini disebabkan kedua putusan tersebut tidak memuat adanya hak atas suatu prestasi, maka terjadinya akibat hukum tidak tergantung pada bantuan atau kesediaan dari pihak yang dikalahkan, sehingga tidak diperlukan sarana pemaksa untuk melaksanakannya. Apabila pihak yang kalah sudah mau menjalankan putusan tersebut secara sukarela, maka perkara perdata tersebut dianggap selesai tanpa mendapat bantuan dari pengadilan dalam melaksanakan putusan tersebut. Namun sering terjadi bahwa pihak yang dikalahkan tidak mau menjalankan putusan tersebut secara suka rela, sehingga diperlukan bantuan pengadilan untuk melaksanakan putusan tersebut secara paksa, dengan cara pihak yang dimenangkan dalam putusan dapat mohon pelaksanaan putusan (eksekusi) kepada pengadilan yang melaksanakan dengan paksa (execution force).
Pelaksanaan putusan pengadilan dalam perkara perdata dilakukan oleh panitera dan Juru Sita dipimpin oleh ketua pengadilan sebagaimana pasal 54 ayat (2) UndangUndang No. 48 Tahun 2009 tentang Kekuasaan Kehakiman. Di samping itu dalam melaksanakan putusan pengadilan juga dengan memperhatikan nilai kemanusiaan dan keadilan sebagaimana pasal 54 ayat (3) Undang-Undang No. 48 Tahun 2009 tentang Kekuasaan Kehakiman. Berkaitan dengan pelaksanaan putusan ini juga ditentukan dalam HIR Pasal 195-224 dan Rbg Pasal 206240 Rbg dan 258 Rbg). Pelaksanaan putusan atas perintah dan di bawah Ketua pengadilan Negeri, yang dimaksud ketua pengadilan negeri yang dulu memeriksa, memutuskan perkara itu dalam tingkat pertama (Pasal 195 ayat (1) HIR dan Rbg Pasal 206 ayat (1)). Dengan perkataan lain eksekusi tidak dapat dijalankan oleh pengadilan Tinggi dan Mahkamah Agung.

Pelaksanaan putusan hakim atau eksekusi pada hakikatnya merupakan realisasi dari kewajiban pihak yang bersangkutan (dikalahkan) untuk memenuhi prestasi yang tercantum dalam putusan tersebut. Namun dalam praktik di lapangan sering terjadi perlawanan dari pihak yang akan dieksekusi terhadap alat-alat negara yang melaksanakan eksekusi tersebut.

\section{Metode}

Pendekatan penelitian ini adalah kualitatif deskriptif. Penelitian ini menekankan kriteria pendekatan kualitatif pada temuan data atau informasi yang bersifat deskriptif dalam bentuk data-data berupa keterangan subjek, uraian kata-kata atau kalimat dan bukan pada data yang terbatas pada angka-angka (Moleong, 2010; Nasution, 2003). Penentuan subjek penelitian ini dengan cara purposive, yakni memilih subjek penelitian secara 
sengaja oleh peneliti berdasarkan kriteria atau pertimbangan tertentu (Sanafiah, 1995, p. 67). Sebagai subjek penelitian yaitu Ketua Pengadilan Negeri Sleman sebagai Pimpinan/komando, Ketua Panitera Pengadilan Negeri Sleman sebagai koordinator, seorang Juru Sita Pengadilan Negeri Sleman sebagai pelaksana dan seorang Juru Sita Pengganti sebagai pelaksana dalam eksekusi putusan hakim dalam sengketa perdata di Pengadilan Negeri Sleman. Data diperoleh melalui wawancara dan dokumentasi. Keabsahan data dilakukan dengan cara cross check dari hasil wawancara antar subjek penelitian dengan data dokumen. Analisis data dilakukan secara induktif melalui reduksi data, display data dan kesimpulan/verifikasi (Miles \& Huberman, 1992, pp. 16-21).

\section{Hasil dan Pembahasan}

Kompetensi suatu pengadilan ada dua macam, pertama kompetensi relatif yang menyangkut wilayah hukum. Kompetensi relatif Pengadilan Negeri Sleman adalah seluruh wilayah administratif pemerintah daerah Kabupaten Sleman (86 desa dari 17 kecamatan). Menurut Pasal 118 (1) HIR, pengadilan negeri berwenang memeriksa gugatan yang daerah hukumnya, meliputi: tempat tinggal (domisili) tergugat bertempat tinggal; domisili sebenarnya tergugat (jikalau tergugat tidak dikenal tempat tinggalnya); tempat tinggal salah satu tergugat, jika banyak tergugat yang tempat tinggalnya tidak dalam satu daerah hukum pengadilan negeri; tempat tinggal tergugat utama jika hubungan antara tergugat-tergugat adalah sebagai yang berhutang dan penjamin. Di samping itu tempat tinggal penggugat atau salah satu dari penggugat dalam hal: ((1) tergugat tidak diketahui tempat tinggal dan tidak diketahui dimana ia berada; (2) tergugat tidak dikenal;
(3) dalam hal tersebut di atas dan yang menjadi objek gugatan adalah benda tidak bergerak (tanah), maka ditempat benda tidak bergerak tersebut terletak. Berbeda dengan Rbg Pasal 142, apabila objek gugatan adalah tanah, maka gugatan selalu dapat diajukan kepada pengadilan negeri di mana tanah tersebut terletak. Ketentuan tersebut mempunyai pengaruh terhadap banyaknya yustisiabel (justiciabelen) di Pengadilan Negeri Sleman di bidang pertanahan. Apabila Sleman sebagai daerah yang perkembangannya pesat, masalah tanah merupakan permasalahan yang sangat krusial.

Selanjutnya kompetensi absolut yang terkait dengan bidang perkara yang menjadi kewenangan Pengadilan Negeri Sleman. Sebagaimana lembaga peradilan umum tingkat pertama yakni memutus perkara perdata dan perkara pidana yang tidak menjadi kompetensi badan peradilan lainnya (Peradilan Agama, TUN dan Militer) pada tingkat pertama. Dalam bidang perdata, kewenangan Pengadilan Negeri Sleman meliputi bidang hukum tentang "Orang", Hukum Keluarga, Hukum Harta Kekayaan (termasuk perjanjian) serta hukum waris sepanjang tidak menjadi kewenangan lingkungan Peradilan Agama.

Pelaksanaan/eksekusi putusan hakim dalam sengketa perdata di Pengadilan Negeri Sleman dari tahun 2010 sampai dengan 2013 permohonan eksekusi yang terdaftar sejumlah 220 berkas (Kepaniteraan Pengadilan Negeri Sleman, 2013). Dari permohonan eksekusi tersebut yang eksekusinya terlaksana sejumlah 143, dan 77 sisanya belum terlaksana eksekusinya atau bergantung.

Keadaan perkara perdata yang dimohonkan eksekusi di Pengadilan Negeri Sleman dari tahun 2010 sampai 19 Agustus 2013, dari 77 berkas permohonan eksekusi 
yang belum terlaksana atau masih bergantung tersebut, sebagian besar dari berkas permohonan eksekusi riil pengosongan tanah atau rumah yakni 66 berkas dan sebagian kecil jenis eksekusi pembayaran sejumlah uang yakni 5 berkas permohonan eksekusi, dan sisanya 6 berkas permohonan eksekusi hak tanggungan (HT) di luar putusan hakim yakni 6 berkas permohonan eksekusi. Untuk kejelasannya dapat dilihat pada tabel berikut ini.

Tabel Eksekusi yang Belum

Terlaksana/Bergantung dari Tahun 2010

Sampai 19 Agustus 2013 di Pengadilan Negeri Sleman

\begin{tabular}{|c|c|c|}
\hline No & $\begin{array}{c}\text { Jenis Permohonan } \\
\text { Eksekusi yang Belum } \\
\text { Terlaksana/ } \\
\text { Bergantung }\end{array}$ & Jumlah \\
\hline 1 & $\begin{array}{ll}\text { Eksekusi } & \text { Riil } \\
\text { pengosongan tanah atau } \\
\text { rumah }\end{array}$ & $\begin{array}{c}66 \\
\text { berkas }\end{array}$ \\
\hline 2 & $\begin{array}{l}\text { Eksekusi Pembayaran } \\
\text { sejumlah uang }\end{array}$ & 5 berkas \\
\hline 3 & $\begin{array}{l}\text { Eksekusi di luar putusan } \\
\text { Hakim (Eksekusi Hak } \\
\text { Tanggungan) }\end{array}$ & 6 berkas \\
\hline & Jumlah & $\begin{array}{c}77 \\
\text { berkas }\end{array}$ \\
\hline
\end{tabular}

Adapun berbagai alasan penundaan eksekusi putusan hakim dalam perkara perdata gugatan di Pengadilan Negeri Sleman antara lain karena: eksekusi ditunda, ada perlawanan, pemohon mengajukan verzet, setelah ditegur pemohon belum memberi keterangan, pemohon baru mencari barang milik termohon untuk disita, ada gugatan baru, tergugat membayar biaya eksekusi hanya sebagian, taraf eksekusi, untuk menjual sulit, pemohon mencabut permohonan eksekusi, penyitaan, taraf teguran, menunggu fatwa dari pengadilan tinggi yogyakarta dan taraf sita.
Pejabat yang menjalankan eksekusi putusan hakim dalam sengketa perdata di Pengadilan Negeri adalah:

1. Ketua Pengadilan Negeri Sleman yang memimpin pelaksanaan putusan hakim dalam perkara perdata

2. Panitera Pengadilan Negeri Sleman, antara lain bertugas mengurus daftar perkara, administrasi perkara, administrasi keuangan perkara dan administrasi pelaksanaan putusan perkara perdata dan menunjuk Juru Sita untuk melaksanakan eksekusi. Dalam perkara perdata, panitera bertugas melaksanakan putusan pengadilan. Di samping itu bertugas menunjuk panitera pengganti untuk membantu hakim dalam persidangan, menunjuk Juru Sita untuk melaksanakan eksekusi. Selanjutnya panitera pengganti di Pengadilan Negeri Sleman sejumlah 24 (dua puluh empat) orang.

3. Juru Sita dan Juru Sita Pengganti yang bertugas antara lain bertugas: melakukan penyitaan atas perintah ketua pengadilan negeri, membuat berita acara penyitaan yang salinan resminya diserahkan kepada pihak-pihak yang berkepentingan. Semua tugas itu harus dilaksanakan dengan saksama dan tertib (Pasal 65 UndangUndang Republik Indonesia Nomor 2 Tahun 1986 tentang Peradilan Umum jo Undang-Undang Republik Indonesia Nomor 8 Tahun 2004 tentang Perubahan atas Undang-Undang Nomor 2 Tahun 1986 tentang Peradilan Umum jo UndangUndang Republik Indonesia Nomor 49 Tahun 2009 tentang Perubahan Kedua Atas Undang-Undang Nomor 2 Tahun 1986 tentang Peradilan Umum).

Eksekusi putusan hakim dalam sengketa perdata di Pengadilan Negeri Sleman diawali 
dari pengajuan permohonan eksekusi oleh pemohon eksekusi dan berakhir dengan pelaksanaan/eksekusi putusan hakim dalam sengketa perdata.

Eksekusi baru bisa dijalankan apabila Putusan Pengadilan Negeri (hakim) dalam perkara perdata telah memperoleh kekuatan hukum tetap, kecuali dalam putusan yang dapat dijalankan lebih dahulu atau dalam putusan provisi. Dengan kata lain eksekusi putusan pengadilan baru dapat dijalankan apabila putusan yang bersangkutan sudah tidak mungkin lagi diajukan upaya banding atau kasasi. Putusan pengadilan dalam perkara perdata yang dapat dilakukan eksekusi hanya putusan yang bersifat condemnatoir.

Kewenangan Pengadilan Negeri Sleman untuk menjalankan eksekusi apabila pihak tergugat (termohon eksekusi) tidak bersedia menjalankan putusan secara suka rela. Eksekusi baru merupakan alternatif hukum apabila tergugat tidak menjalankan putusan secara suka rela. Seorang tergugat dianggap patut menjalankan putusan secara suka rela dalam waktu satu minggu atau sepuluh hari dari sejak tanggal putusan mempunyai kekuatan hukum tetap diberitahukan secara resmi kepada tergugat. Apabila sudah lewat, namun tergugat tidak mau menjalankan putusan secara sukarela, maka tergugat sudah dapat dianggap ingkar menjalankan putusan secara suka rela. Oleh karena itu sejak hari itu sudah terbuka jalan untuk eksekusi oleh Pengadilan Negeri Sleman atas permohonan eksekusi secara tertulis dari pemohon eksekusi (penggugat) yang menang. Pengajuan Permohonan tersebut dapat dilakukan secara pribadi atau melalui kuasanya.

Pihak pemohon eksekusi/kuasanya dalam mengajukan permohonan eksekusi disertai dengan melampirkan fotokopi putusan pengadilan yang telah mempunyai kekuatan hukum tetap dari Putusan Pengadilan Negeri Sleman, dan/atau Putusan Pengadilan Tinggi Yogyakarta, dan atau Putusan Mahkamah Agung Republik Indonesia.

Pengajuan permohonan eksekusi dari pemohon eksekusi melalui Kepaniteraan Perdata Pengadilan Negeri Sleman, yakni Panitera Muda Perdata disertai dengan membayar panjar eksekusi, besarnya disesuaikan situasi dan kondisi dari objek sengketa perdata. Biaya eksekusi riil yang harus dibayar oleh pihak pemohon sesuai dengan Keputusan Ketua Pengadilan Negeri Sleman tanggal 1 Mei tahun 2012 Nomor: W13.U2/2307/PA.01.05/2012 tentang Taksiran Panjar (Voorschot). Apabila para pihak berdomisili pada Radius lain dan atau jumlah pihak lebih dari 1 (satu), maka penghitungan panjar disesuaikan dengan domisili masing-masing pihak sebagaimana diatur dalam angka I Keputusan Ketua pengadilan Negeri Sleman Nomor: W13.U2/2307/PA.01.05/2012 tentang Taksiran Panjar (Voorschot) Biaya Perkara Perdata Pada Pengadilan Negeri Sleman.

Selanjutnya setelah pemohon menyetor biaya panjar eksekusi ke rekening Kepaniteraan Pengadilan Negeri Sleman melalui Bank Rakyat Indonesia (BRI), pemohon eksekusi menyerahkan bukti penyetoran tersebut kepada kasir yang berada di bagian Kepaniteraan Perdata Pengadilan Negeri Sleman. Selanjutnya kasir mengeluarkan tanda bukti pembayaran berupa Surat Kuasa Untuk Membayar (SKUM). SKUM panjar biaya eksekusi di buat 3 (tiga) rangkap, lembar pertama untuk pemohon eksekusi, lembar kedua untuk berkas dan lembar ketiga untuk arsip kasir. Kemudian Panitera Pengadilan Negeri 
Sleman mengecek identitas pihak pemohon. Apabila pemohon tidak secara langsung atau mewakilkan/memberikan kuasa, maka perlu dicek surat kuasa dari pihak pemohon eksekusi. Oleh karena itu dalam pengajuan permohonan eksekusi yang dilakukan seorang kuasa, tetap berlaku ketentuan umum pemberian kuasa, yakni agar tindakan hukum yang dilakukan kuasa memenuhi syarat formal harus berdasar surat "kuasa khusus" (Harahap, 1988, p. 27).

Dari uraian tersebut menunjukkan bahwa pelaksanaan eksekusi putusan hakim harus diminta oleh pihak yang menang dalam perkara dan tidak dapat dilaksanakan secara ex officio. (HR. 4 Nopember 1955, N.J.1956,177, HR 8 Oktober 1982, N.J. 1984, 58 dalam Mertokusumo 1993:261).

Apabila hasil pengecekan identitas pemohon lengkap, maka Ketua Pengadilan Negeri Sleman memerintahkan Juru Sita atau Juru Sita pengganti untuk melakukan pemanggilan kepada tergugat (yang dikalahkan) atau termohon eksekusi dan pemohon eksekusi dengan surat panggilan untuk menghadap di Pengadilan Negeri Sleman pada hari, tanggal, dan waktu yang telah ditentukan. sebagai bukti bahwa surat panggilan kepada termohon sudah diterima.

Setelah kedua pihak (pemohon dan termohon hadir), Ketua Pengadilan Negeri Sleman berupaya agar pihak pemohon eksekusi dengan termohon eksekusi untuk berunding, untuk diselesaikan secara kekeluargaan atau melakukan musyawarah/negosiasi. Hal ini dilakukan oleh Ketua Pengadilan Negeri Sleman, karena lebih mengutamakan penyelesaian secara kekeluargaan, dengan harapan dengan cara tersebut bagi pihak termohon eksekusi bisa melaksanakan putusan hakim secara suka rela.
Berkaitan dengan uraian tersebut di atas dalam praktik, sering terjadi pihak termohon Eksekusi minta tempo waktu/kesanggupan memenuhi isi putusan hakim dengan penundaan yang disepakati oleh Pemohon eksekusi. Namun jika kesepakatan tersebut tidak dilaksanakan oleh Termohon eksekusi, misalnya dalam eksekusi riil untuk mengosongkan tanah atau rumah, mulai hari itu terhitung melakukan teguran (aanmaning) kepada termohon eksekusi oleh Ketua Pengadilan Negeri Sleman.

Tenggang waktu aanmaning (peringatan) yang diberikan oleh Ketua Pengadilan Negeri maksimum 8 (delapan) hari (Pasal 196 HIR/207 Rbg). Maksudnya dalam batas waktu peringatan yang diberikan tergugat diminta untuk menjalankan putusan secara suka rela dan apabila batas waktu peringatan yang ditetapkan dilampaui dan tergugat tetap tidak mau menjalankan putusan, maka sejak saat itu putusan sudah dapat dieksekusi dengan paksa.

Apabila dalam waktu 8 (delapan) hari sejak teguran, termohon tidak melaksanakan isi putusan hakim dalam perkara perdata, maka eksekusi putusan hakim tersebut secara otomatis untuk dijalankan. Dengan perkataan lain apabila tidak diperoleh titik temu antara Pemohon dengan termohon eksekusi, selanjutnya Ketua Pengadilan Negeri memberikan aanmaning (peringatan) berupa teguran kepada pihak termohon eksekusi agar menjalankan isi putusan pengadilan dalam tempo yang ditentukan oleh Ketua Pengadilan Negeri Sleman yakni 8 hari sejak adanya teguran/aanmaning.

Peringatan tersebut dilakukan dalam pemeriksaan sidang insidental yang dihadiri oleh Ketua Pengadilan Negeri Sleman, Panitera, dan pihak-pihak yang kalah atau termohon eksekusi. Dalam persidangan 
insidental tersebut diberitahukan permohonan eksekusi dari pihak penggugat (yang menang) dan agar tergugat menjalankan putusan dalam waktu yang ditentukan selama peringatan yakni 8 hari. Semua peristiwa yang terjadi dalam persidangan pemberian peringatan tersebut dicatat oleh panitera dalam berita acara, sebagai bukti autentik sidang pemberian peringatan kepada tergugat. Berita acara peringatan tersebut sangat penting untuk mendukung dan menjadi sumber landasan bagi keabsahan perintah eksekusi selanjutnya.

Sebagai

lanjutan

dari

aanmaning/peringatan, pihak termohon tidak mau menjalankan putusan secara suka rela adalah pengeluaran "Surat Penetapan Perintah Eksekusi atau "Penetapan "yang ditetapkan oleh Ketua Pengadilan Negeri Sleman berisi perintah menjalankan eksekusi. Perlu diketahui sebelum eksekusi tersebut dijalankan sebagaimana telah dikemukakan di atas eksekusi putusan hakim dalam perkara perdata yang telah terlaksana di Pengadilan Negeri Sleman adalah eksekusi pembayaran sejumlah uang dan eksekusi riil tentang pengosongan tanah atau rumah.

Setelah aanmaning, dengan Surat Perintah atau Penetapan" untuk menjalankan eksekusi, Panitera Pengadilan Negeri Sleman memeriksa/mengecek apakah sudah ada sita conservatoir terhadap barang-barang milik termohon eksekusi. Apabila belum ada, maka dilakukan sita eksekusi terlebih dahulu terhadap barang-barang milik Termohon eksekusi. Sesuai ketentuan Pasal 197 ayat (1) HIR, penyitaan lebih dahulu dilakukan terhadap barang-barang bergerak, jika barang-barang bergerak tidak ada atau tidak mencukupi, barulah dilakukan terhadap barang-barang tidak bergerak. Hal ini dilakukan, karena secara konkrit eksekusi putusan yang menghukum tergugat untuk membayar sejumlah uang adalah menguangkan barang tertentu dari harta kekayaan pihak yang dikalahkan/tergugat atau debitur dengan tujuan untuk memenuhi putusan guna kepentingan pihak yang dimenangkan/penggugat. Oleh karena itu harta kekayaan tersebut harus disita/dibekukan terlebih dahulu untuk kemudian dilakukan sita eksekutorial. Dengan kata lain sebelum eksekusi putusan dijalankan, lebih dahulu harus diadakan sita eksekusi, kecuali sebelumnya telah diadakan sita conservatoir. Sita conservatoir ini setelah putusan dijatuhkan akan mendapat titel eksekutorial. Tujuan sita conservatoir adalah untuk menjamin terlaksananya putusan, berfungi untuk membekukan harta kekayaan debitur yang lebih penting, sedangkan sita eksekutorial fungsi penjualannya.

Selanjutnya setelah diletakkan sita eksekusi atas barang-barang bergerak maupun barang-barang tidak bergerak milik termohon eksekusi, kemudian Ketua Pengadilan Negeri Sleman mengeluarkan penetapan perintah penjualan lelang terhadap barang-barang milik pihak yang kalah perkara sampai mencukupi jumlah uang yang harus dikeluarkan guna pelaksanaan putusan hakim dan ditambah semua biaya sehubungan dengan pelaksanaan putusan tersebut dan uang hasil lelang tersebut nantinya akan diserahkan kepada pemohon eksekusi sebagai pemenuhan isi putusan. Pengadilan Negeri Sleman dalam hal ini melalui Juru Sita yang ditunjuk oleh Ketua Pengadilan Negeri Sleman dalam melakukan pelelangan dengan perantaraan Kantor Pelayanan dan Lelang Negara Yogyakarta, karena pelelangan yang dilakukan diatas Rp. 300, - sebagaimana ditegaskan dalam Pasal 200 HIR ayat (1) dan (2), menentukan bahwa penjualan dilakukan 
dengan pertolongan kantor lelang, dan untuk membayar jumlah uang yang kurang dari Rp 300,- boleh oleh Juru Sita.

Sebelum pelelangan harus diumumkan dalam waktu delapan hari setelah penyitaan. Apabila yang dilelang termasuk barang tidak bergerak, maka harus diumumkan dua kali dengan selang lima belas hari. Di samping itu apabila yang dilelang itu berupa barang tidak bergerak yang berharga lebih dari Rp. 1.000, - harus diumumkan dalam surat kabar yang terbit di dekat kota paling lama empat belas hari sebelum pelelangan. Selanjutnya apabila harga lelang telah dibayar, hak atas barang tidak bergerak segera beralih kepada pembeli. Kepada pembeli diberikan surat lunas orang yang kena lelang dan keluarganya serta sanak saudaranya harus menyerahkan barang tidak bergerak itu secara kosong kepada pembeli. Apabila termohon enggan melakukan hal tersebut, Ketua Pengadilan Negeri mengeluarkan surat perintah pengosongan, dan pengosongan dilakukan dengan paksa.

Meskipun dalam HIR tidak mengatur tentang eksekusi riil, namun dalam Pasal 200 ayat (11) yang mengatur lelang, menyebutkan eksekusi riil "jika perlu dengan pertolongan polisi, barang tetap itu ditinggalkan dan dikosongkan oleh orang yang dijual barangnya, serta oleh sanak saudaranya". Pasal ini memberikan petunjuk sedikit tentang bagaimana eksekusi riil harus dijalankan. Pengosongan dilakukan juru sita apabila perlu dibantu oleh beberapa anggota Polisi atau anggota TNI.

Walaupun eksekusi riil tidak secara baik diatur dalam HIR, eksekusi riil sudah lazim dilakukan, oleh karena dalam praktik sangat diperlukan. Pasal 1033 R.V mengatur tentang eksekusi riil ini jika putusan hakim yang memerintahkan pengosongan suatu barang yang tidak bergerak, tidak dipenuhi olehnya orang yang dihukum, maka ketua akan memerintahkan dengan surat kepada seorang Juru Sita supaya dengan bantuannya alat kekuasaan negara, barang itu dikosongkan oleh orang yang dihukum serta keluarganya dan segala barang kepunyaannya.

Sehubungan dengan Eksekusi Riil pengosongan tanah atau rumah hal tersebut di atas yang telah terlaksana di Pengadilan Negeri Sleman, tidak harus dengan sita eksekusi sedang untuk eksekusi pembayaran sejumlah uang diperlukan sita eksekusi lebih dahulu kecuali sudah terjadi sita conservatoir pada waktu gugatan diajukan atau dalam pemeriksaan di persidangan.

Pelaksana eksekusi dalam hal ini juru sita sering menemui permasalahan yang terkait dengan eksekusi riil yang berupa pengosongan tanah (pembongkaran bangunan) dan pengosongan rumah (mengeluarkan barang-barang yang ada dalam rumah milik termohon). Pihak petugas dalam menghadapi masalah tersebut melakukan secara manusiawi minta pada Pemohon eksekusi untuk menempatkan penampungan baik orang atau barang-barang milik termohon, karena kalau ditempatkan atau ditaruh di jalan, masyarakat sekitar objek eksekusi merasa keberatan.

Eksekusi dapat ditangguhkan tidak selalu mulus, apabila ada perlawanan secara hukum yang mengabulkan misalnya Peninjauan Kembali oleh pihak termohon. Di samping itu jika terjadi di lapangan situasi dan kondisi keamanan tidak kondusif (mengancam petugas), terjadi pengumpulan masa baik dari pihak pemohon maupun dari termohon. Apabila dilanjutkan akan banyak korban dari kedua belah pihak maupun dari petugas. Sesuai dengan petunjuk Mahkamah Agung dalam Keputusan Ketua Mahkamah Agung Republik Indonesia No: 
KMA/032/SK/IV/2006

tentang

Pemberlakuan Buku II Pedoman Pelaksana Tugas dan Administrasi Pengadilan, apabila memungkinkan eksekusi bisa ditangguhkan.

Hambatan dalam eksekusi putusan hakim dalam sengketa perdata di Pengadilan Negeri Sleman diantaranya banyaknya biaya yang harus ditanggung pemohon eksekusi merupakan faktor yang menghambat eksekusi di Pengadilan Negeri Sleman. Besarnya biaya resmi panjar yang harus disetorkan pemohon eksekusi ke atas nama rekening Kepaniteraan Pengadilan Negeri Sleman melalui BRI sebesar Rp.2.500.000, - (dua juta lima ratus ribu rupiah), jika sita eksekusi sebesar Rp. 1.500.000, - (satu juta lima ratus ribu rupiah), maka pemohon eksekusi menyetor biaya sita eksekusi sebesar Rp. 4.000.000, - (empat juta rupiah). Di samping itu apabila eksekusi tidak dapat dilakukan secara sukarela, sehingga perlu bantuan aparat keamanan, maka pemohon eksekusi harus mengeluarkan biaya keamanan eksekusi. Kemudian apabila eksekusi riil pengosongan tanah atau rumah, pemohon juga harus menyediakan transportasi serta tempat untuk menyimpan barang-barang bergerak milik termohon eksekusi, maka akan menambah biaya yang harus dikeluarkan oleh pemohon eksekusi. Apabila biaya tersebut belum dipenuhi, maka eksekusi belum terlaksana. Salah satu contoh alasan belum terlaksananya permohonan eksekusi/bergantung, karena pemohon belum menambah biaya.

Pengadilan Negeri Sleman kekurangan personil petugas yang menjalankan eksekusi, karena hanya memilki 4 (empat) juru sita yaitu Sumaryoto; Suprihatin; F.X. Sumeru dan Slamet Paryanto, yang surat keputusannya dari Dirjen Peradilan Umum. Di samping itu, juga membutuhkan pegawai selain juru sita, tetapi yang menentukan atau merekrut pegawai adalah Mahkamah Agung.

Hambatan yang sering ditemui oleh petugas lapangan atau Juru Sita Pengadilan Negeri Sleman dalam eksekusi putusan hakim pada perkara perdata terutama ketika akan menjalankan putusan/eksekusi putusan riil pengosongan tanah atau rumah. Hambatan tersebut adanya perlawanan dari termohon eksekusi dengan pengerahan massa untuk menghalang-halangi eksekusi yang dilakukan oleh Juru Sita.

Untuk mengatasi hambatan-hambatan tersebut di atas Pengadilan Negeri Sleman telah berupaya guna meminimalisir adanya hambatan-hambatan yang ditemui ketika petugas eksekusi menjalankan eksekusi putusan hakim dalam sengketa perdata meskipun belum memperoleh hasil yang maksimal. Adapun upaya yang telah dilakukan oleh Pengadilan Negeri Sleman dalam mengatasi hambat-hambatan dalam eksekusi putusan hakim dalam sengketa perdata tersebut sebagai berikut.

Untuk mengurangi beban biaya yang ditanggung oleh pemohon eksekusi, yang dilakukan oleh Ketua Pengadilan Negeri Sleman dengan cara memanggil pihak pemohon eksekusi untuk lebih aktif menyelesaikan secara kekeluargaan dengan harapan termohon eksekusi mau menjalankan eksekusi secara sukarela, sehingga tidak perlu dengan bantuan aparat keamanan.

Dalam mengatasi hambatan kekurangan personil petugas eksekusi riil putusan hakim dalam sengketa perdata, Pengadilan Negeri Sleman telah berupaya dengan memperbantukan Juru Sita Pengganti untuk melakukan pemanggilan kepada pihak pemohon maupun termohon eksekusi. Juru Sita Pengganti tersebut rata-rata memang sudah dirangkap oleh staf dari Pengadilan 
Negeri Sleman. Di samping itu setiap tahun Ketua Pengadilan Negeri telah mengupayakan untuk penambahan personil petugas eksekusi (Juru Sita) kepada Mahkamah Agung meskipun sampai saat penelitian ini dilakukan belum terpenuhi.

Upaya untuk mengatasi hambatan perlawanan dari termohon eksekusi khususnya eksekusi riil pengosongan rumah dan pengosongan tanah dengan adanya perlawanan dari pihak termohon eksekusi atau adanya pengerahan massa untuk menghalang-halangi petugas eksekusi, Ketua Pengadilan Negeri Sleman berupaya menunggu dari kesiapan aparat keamanan agar situasinya yang kondusif. Apabila terjadi perlawanan atau pengerahan massa seperti tersebut di atas, pasti Juru Sita menginformasikan lewat media elektronik kepada Ketua Pengadilan Negeri sebagai pimpinan dalam eksekusi tersebut. Ketua Pengadilan Negeri cukup mengomando dari Pengadilan Negeri, kalau Juru Sita tidak berani untuk menjalankan eksekusi, maka Ketua Pengadilan Negeri memerintahkan secara lisan (dalam keadaan mendesak) eksekusi untuk ditangguhkan, yang kemudian dituangkan dalam Penetapan Pengadilan Negeri tentang penangguhan eksekusi, tanggal dan hari serta tahunnya sesuai dengan penetapan secara lisan.

\section{Simpulan}

Diawali adanya pengajuan permohonan dari pemohon eksekusi kepada Ketua Pengadilan Negeri yang disertai dengan bukti pembayaran biaya panjar eksekusi dari Kepaniteraan Perdata dan kasir berupa SKUM (Surat Kuasa untuk Membayar). Selanjutnya Juru Sita atas perintah Ketua PN Sleman melakukan pemanggilan kepada pihak termohon dan pemohon eksekusi untuk menyelesaikan secara kekeluargaan, sehingga termohon menjalankan putusan secara sukarela. Apabila dalam waktu yang ditentukan tidak ada kata sepakat atau termohon ingkar, maka Ketua Pengadilan Negeri memberikan aanmaning kepada termohon. Delapan hari setelah aanmaning termohon tidak mau menjalankan putusan secara suka, maka Ketua Pengadilan Negeri mengeluarkan surat perintah eksekusi atau penetapan yang berisi perintah untuk menjalankan eksekusi kepada juru sita. Sebelum Eksekusi dilaksanakan terlebih dahulu dilakukan sita eksekusi kecuali sebelumnya ada sita conservatoir untuk eksekusi pembayaran sejumlah uang dengan tujuan untuk diuangkan melalui lelang yang hasilnya diserahkan kepada pemohon eksekusi yang sesuai dengan isi putusan pengadilan.

Eksekusi Riil pengosongan tanah dan rumah dinyatakan selesai dengan diterimanya objek eksekusi riil pengosongan tanah dan rumah oleh pemohon eksekusi yang dimuat dalam Berita Acara Eksekusi/Pelaksanaan Isi Putusan Pengadilan Sleman. Demikian juga untuk eksekusi pembayaran sejumlah uang dinyatakan selesai dengan diterimanya sejumlah uang oleh pemohon eksekusi yang sesuai dengan isi putusan untuk eksekusi pembayaran sejumlah uang, yang dituangkan dalam Berita Acara Eksekusi/Pelaksanaan Isi Putusan Pengadilan Negeri Sleman.

Hambatan-hambatan dalam eksekusi putusan dalam perkara perdata di Pengadilan diantaranya beban biaya yang ditanggung pemohon eksekusi, personil petugas eksekusi dan perlawanan dari termohon eksekusi.

Upaya Mengatasi Hambatan dalam Eksekusi Putusan Hakim dalam Sengketa Perdata di Pengadilan Negeri Sleman

a. Upaya untuk mengatasi beban biaya yang ditanggung oleh pemohon eksekusi 
Untuk mengurangi beban biaya yang ditanggung oleh pemohon eksekusi, yang dilakukan oleh Ketua PN Sleman dengan cara memanggil pihak pemohon eksekusi untuk lebih aktif menyelesaikan secara kekeluargaan. Hal ini dilakukan dengan harapan termohon eksekusi mau menjalankan eksekusi secara suka rela, sehingga tidak perlu dengan bantuan aparat keamanan.

b. Personil petugas eksekusi

Dalam mengatasi hambatan kekurangan personil petugas eksekusi riil putusan hakim dalam sengketa perdata, Ketua Pengadilan Negeri Sleman telah berupaya dengan memperbantukan Juru Sita Pengganti untuk melakukan pemanggilan kepada pihak Pemohon maupun Termohon eksekusi. Setiap tahun Ketua Pengadilan Negeri telah mengupayakan untuk penambahan personil petugas eksekusi (Juru Sita) kepada Mahkamah Agung meskipun sampai saat penelitian ini dilakukan belum terpenuhi.

c. Upaya untuk mengatasi hambatan Perlawanan dari Termohon eksekusi

Dalam eksekusi riil pengosongan rumah dan pengosongan tanah yakni adanya perlawanan dari pihak Termohon eksekusi atau adanya pengerahan massa, upaya yang dilakukan menunggu dari kesiapan aparat keamanan /situasinya yang kondusif melalui informasi dari Juru Sita lewat media elektronik kepada Ketua Pengadilan Negeri sebagai Pimpinan dalam eksekusi tersebut. Ketua Pengadilan Negeri cukup mengomando dari Pengadilan Negeri.

\section{Daftar Pustaka}

Harahap, M. Y. (1988). Ruang lingkup permasalahan eksekusi bidang perdata. Jakarta: Gramedia.

Kepaniteraan Pengadilan Negeri Sleman. (2013). Buku rekapitulasi perkara perdata. Sleman.

Mertokusumo, S. (1993). Bab-bab tentang penemuan hukum. Jakarta: Citra Aditya Bakti.

Mertokusumo, S. (1999). Hukum acara perdata Indonesia. Yogyakarta: Liberty.

Miles, M. B., \& Huberman, A. M. (1992). Analisis data kualitatif: buku sumber tentang metode-metode baru. Jakarta: Universitas Indonesia Press.

Moleong, L. J. (2010). Metode penelitian kualitatif. Bandung: PT. Remaja Rosdakarya.

Nasution, S. (2003). Metode penelitian naturalistik kualitatif. Bandung: Tarsito.

Sanafiah, F. (1995). Format-format penelitian sosial: dasar-dasar dan aplikasi. Jakarta: Rajawali Pers.

Undang-Undang Republik Indonesia Nomor 2 Tahun 1986 tentang Peradilan Umum.

Undang-Undang Republik Indonesia Nomor 49 Tahun 2009 tentang Perubahan Kedua Atas Undang-Undang Nomor 2 Tahun 1986 tentang Peradilan Umum.

Undang-Undang Republik Indonesia Nomor 8 Tahun 2004 tentang Perubahan atas Undang-Undang Nomor 2 Tahun 1986 tentang Peradilan Umum. 